\title{
Taxonomy, ecology and zoogeography of two East Antarctic freshwater calanoid copepod species: Boeckella poppei and Gladioferens antarcticus
}

\author{
I.A.E. BAYLY1,2, J.A.E. GIBSON ${ }^{3,4 *}$, B. WAGNER ${ }^{5}$ and K.M. SWADLING ${ }^{4}$ \\ ${ }^{1}$ School of Biological Sciences, Monash University, VIC 3800, Australia \\ ${ }^{2} 501$ Killiecrankie Rd, Flinders Island, TAS 7255, Australia \\ ${ }^{3}$ Institute of Antarctic and Southern Ocean Studies, University of Tasmania, Private Bag 77, Hobart, TAS 7001, Australia \\ ${ }^{4}$ School of Zoology, University of Tasmania, Private Bag 5, Hobart, TAS 7001, Australia \\ ${ }_{5}^{5}$ Institute for Geophysics and Geology, Faculty for Physics and Geoscience, University Leipzig, Talstrasse 35, D-04103 Leipzig, Germany \\ *corresponding author: John.gibson@csiro.au
}

\begin{abstract}
New populations of the two species of calanoid copepods known to inhabit freshwater lakes in East Antarctica, Boeckella poppei (Mrázek, 1901) and Gladioferens antarcticus Bayly, 1994, have recently been discovered. The morphology of the populations of B. poppei showed significant differences, notably a reduction in the armature of the male fifth leg, when compared with typical specimens from the Antarctic Peninsula and South America. Gladioferens antarcticus had previously been recorded from a single lake in the Bunger Hills, but has now been recorded from three further lakes in this region. A recent review of Antarctic terrestrial and limnetic zooplankton suggested that neither of these species can be considered an East Antarctic endemic, with B. poppei being listed as a recent anthropogenic introduction and G. antarcticus a 'marine interloper'. We conclude differently: B. poppei has been present in isolated populations in East Antarctica for significant lengths of time, possibly predating the current interglacial, while G. antarcticus is a true Antarctic endemic species whose ancestors have been present in the region since before Australia separated from Antarctica.
\end{abstract}

Received 16 April 2003, accepted 15 September 2003

Key words: Amery Oasis, biogeography, Bunger Hills, ecology, epishelf lake, Gondwana, vicariance

\section{Introduction}

Bayly \& Burton (1993) reported the existence of the calanoid copepod Boeckella poppei (Mrázek, 1901) in Beaver Lake, located in the Amery Oasis of East Antarctica. This population was located thousands of kilometres from previous records of this species, the nearest of which were on or adjacent to the Antarctic Peninsula in West Antarctica. Bayly (1994) described another calanoid, Gladioferens antarcticus Bayly 1994, from the Bunger Hills, also in East Antarctica. This copepod was located thousands of kilometres from its congeners in Australasia. Each of these isolated records were, for several years, associated with only one lake. However, this present paper documents the occurrence of $B$. poppei in two additional lakes in the Amery region, and G. antarcticus from three further lakes in the Bunger Hills.

The existence of these species in East Antarctica raises intriguing questions regarding their biogeography. How did these species come to be in Antarctica? Is their presence a consequence of Holocene dispersal as suggested by Laybourn-Parry \& Marchant (1992) and Pugh et al. (2002), or has the age of certain large lakes in Antarctica been under-estimated, and has one or both of these calanoids had a more ancient association with Antarctica (Bayly \& Burton 1993, Bayly 1994)? One aim of this paper is to address these absorbing questions. Additionally, we provide new information on the taxonomy and ecology of both species.

\section{Methods}

Copepods were collected from lakes in the Bunger Hills (for location of this area and other places mentioned in the text, see Fig. 1) in January 2000, and from lakes in the Amery Oasis in December 2001 and January 2002. Samples were collected by hauling a plankton net (mesh $100 \mu \mathrm{m})$ through the water column to the surface. As all the lakes were icecovered at the time of sampling, the net was deployed through a hole drilled in the ice. Animals were preserved in $4 \%$ formaldehyde (2000) or 30\% ethanol (2001/02).

Temperature and salinity profiles of the lakes of the Bunger Hills were measured as described elsewhere (Gibson \& Andersen 2002). Water samples from the Amery Oasis lakes were collected using a 21 UWITEC water sampler. Once at the surface measurements of temperature (using a WTW Oxi 196 probe), oxygen concentration (WTW Oxi 196) and electrical conductivity (WTW LF 197) were made immediately.

The length of adult calanoids was measured under a stereo-microscope at $25 \mathrm{x}$ magnification using an eyepiece micrometer. Two different lengths were calculated for both 

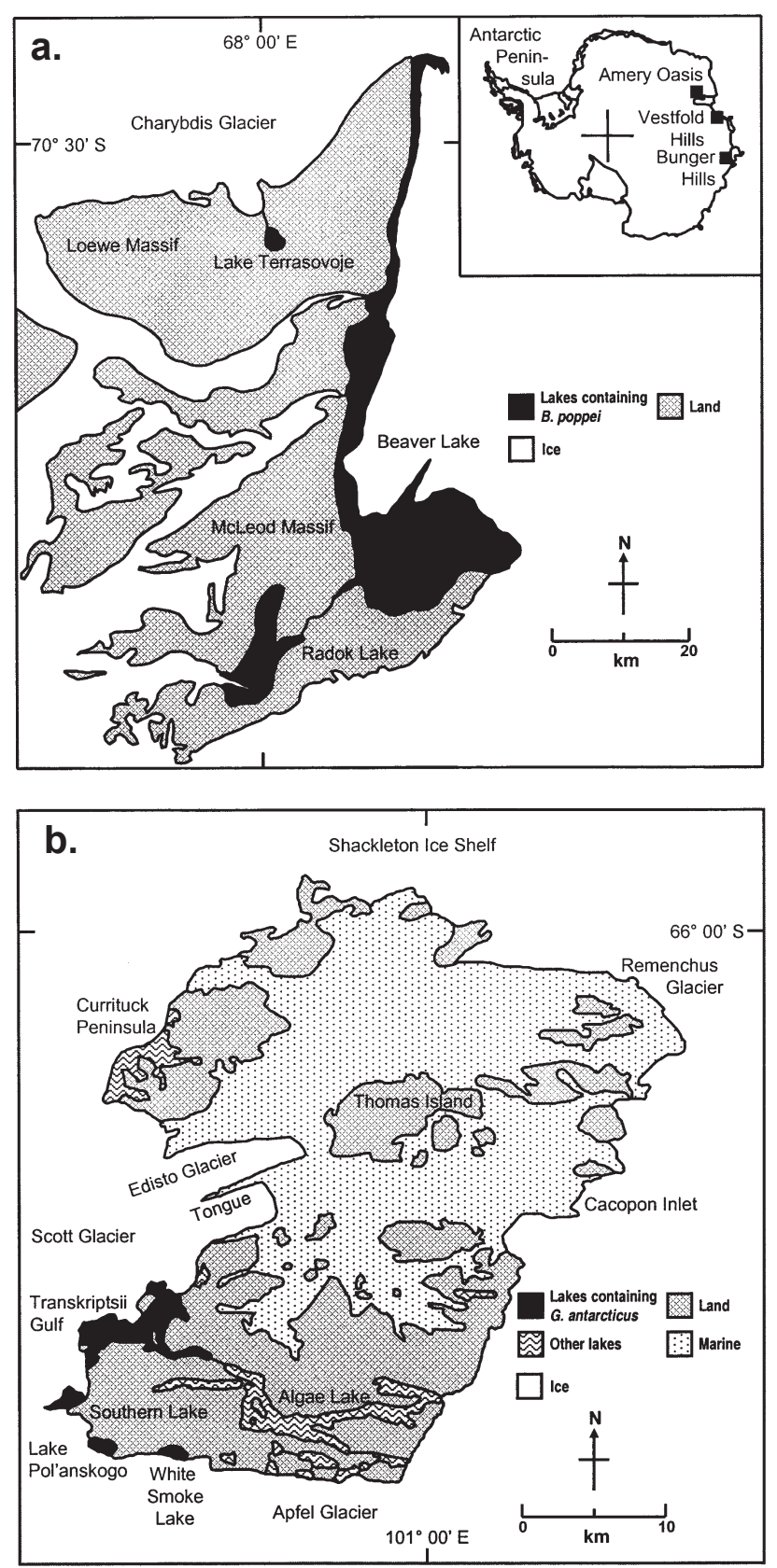

Fig. 1. Maps of a. Amery Oasis, and b. Bunger Hills showing the location of lakes mentioned in the text. The inset in Fig. 1a shows the positions of these localities, as well as others mentioned in the text, on a map of Antarctica.

sexes: the mean length from the anterior extremity of the prosome to the point of insertion of the urosome measured mid-dorsally $(\mathrm{P}[\mathrm{D}] \mathrm{L})$, and the mean length from the anterior extremity of the prosome to the end of the caudal rami (AP-RL). An additional measure for females only was the mean length from the anterior extremity of the prosome to the end of the lateral wings of the last prosome segment (AP-WL).

\section{Results}

Populations of Boeckella poppei from the Amery Oasis

An apparently isolated population of $B$. poppei has previously been recorded from Beaver Lake (Fig. 1a) (Bayly \& Burton 1993). Here we describe aspects of two new populations found in nearby Radok Lake and Lake Terrasovoje and make comparisons with the population in Beaver Lake and with the same species from Patagonia.

\section{Taxonomy of Boeckella poppei}

i) Radok Lake

Material. Seven males and two females collected by B. Wagner on 14 January 2002.

Measurements. Male: P[D]L, $1.02 \mathrm{~mm}(n=7)$; AP-RL, $1.40 \mathrm{~mm}(n=7)$. Female: P[D]L, $1.01 \mathrm{~mm}(n=2)$; AP-WL, $1.18 \mathrm{~mm}(n=2)$; AP-RL, $1.47 \mathrm{~mm}(n=1$ - one female too bent to measure). The AP-RLs for males and females should be compared with the ranges for the corresponding measurements, $1.9-3.0 \mathrm{~mm}$ and $2.2-3.3 \mathrm{~mm}$, given by Bayly (1992b) for populations from lakes near the southern tip of South America.

Male fifth legs. The structure of this appendage found in South American populations is shown in Fig. 2a. Of particular interest is the fact that the terminal segment (Ri3) of the 3-segmented right endopod is armed with four prominent spines - two outer ones that bear secondary teeth and two inner ones which are smooth. (It is convenient to number these spines from 1 for the more proximal of the two outer spines through to 4 for the innermost of the two smooth spines).

The structure of this appendage in five of seven individuals examined from the Radok Lake population is shown in Fig. 2b. The most striking feature when comparing this figure with Fig. 2a is that the right endopod has undergone a marked transformation: the terminal endopod segment has become rounded and is now unarmed, and the entire endopod has become curved. However, this state is not invariable. One of the seven individuals examined had one serrated spine in spine position 1 (Fig. 2c), and one individual had two serrated spines in positions 1 and 2 (Fig. 2d).

There is another significant structural divergence in this appendage. The outer distal spine on the middle right exopod segment (Re2) is greatly reduced (see arrowed spine in Fig. 2). In B. poppei populations in South America this spine extends approximately a third of the distance along the right claw (Re3). Some individuals in the Radok Lake population have a somewhat larger spine in this position (Fig. 2e), but it is still much smaller than that shown in Fig. 2a.

Female fifth legs. One specimen was dissected. The terminal exopod segment (Re3) had a full complement of 

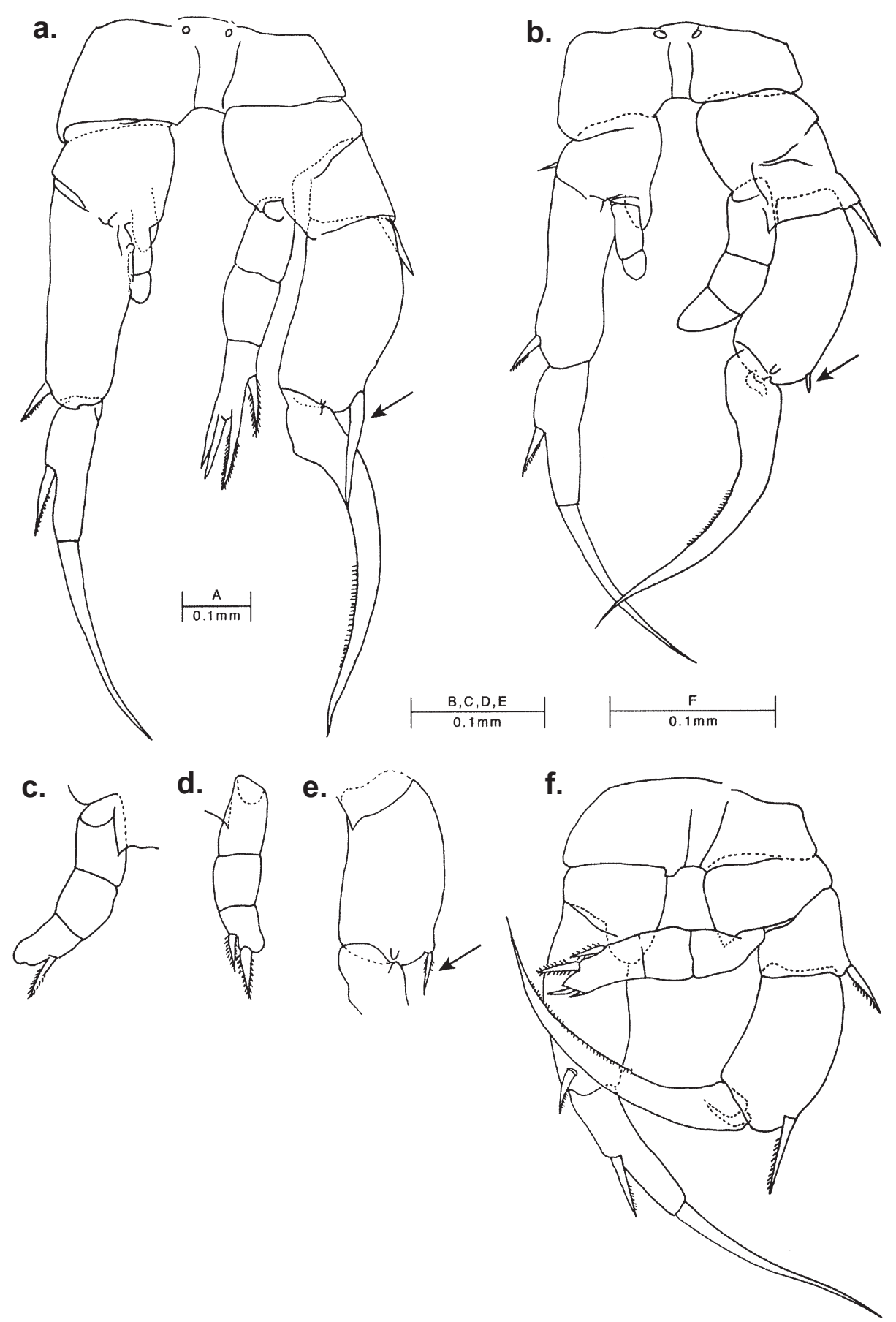

Fig. 2. Boeckella poppei male. a. fifth legs, posterior aspect, drawn from Daday's type material of B. entzii (a synonym of B. poppei) collected from Patagonia. b. Fifth legs, posterior aspect, drawn from a specimen taken from Radok Lake and showing the usual condition for this population. c. Right endopod, posterior aspect, showing an individual from Radok Lake with one serrated spine. d. Right endopod, anterior aspect, showing an individual from Radok Lake with two serrated spines. e. Middle segment of the right exopod, showing an individual from Radok Lake with a somewhat larger outer spine than that shown in Fig. 2b (compare arrowed spines). f. Fifth legs, posterior aspect, drawn from a specimen taken from Beaver Lake. (It is important to note that the right endopod of the only adult male examined has been twisted at its basal attachment so that the outer serrated spines appear to be on the inner edge).

seven spines on both sides but spine number 7 was minute on one side and spine number 6 was minute on the other. The endopods were both 3-segmented, one having five setae on the terminal segment (setal formula 1.1.221), and the other six setae (setal formula 1.1.222). In summary, there was no marked reduction in armature. 

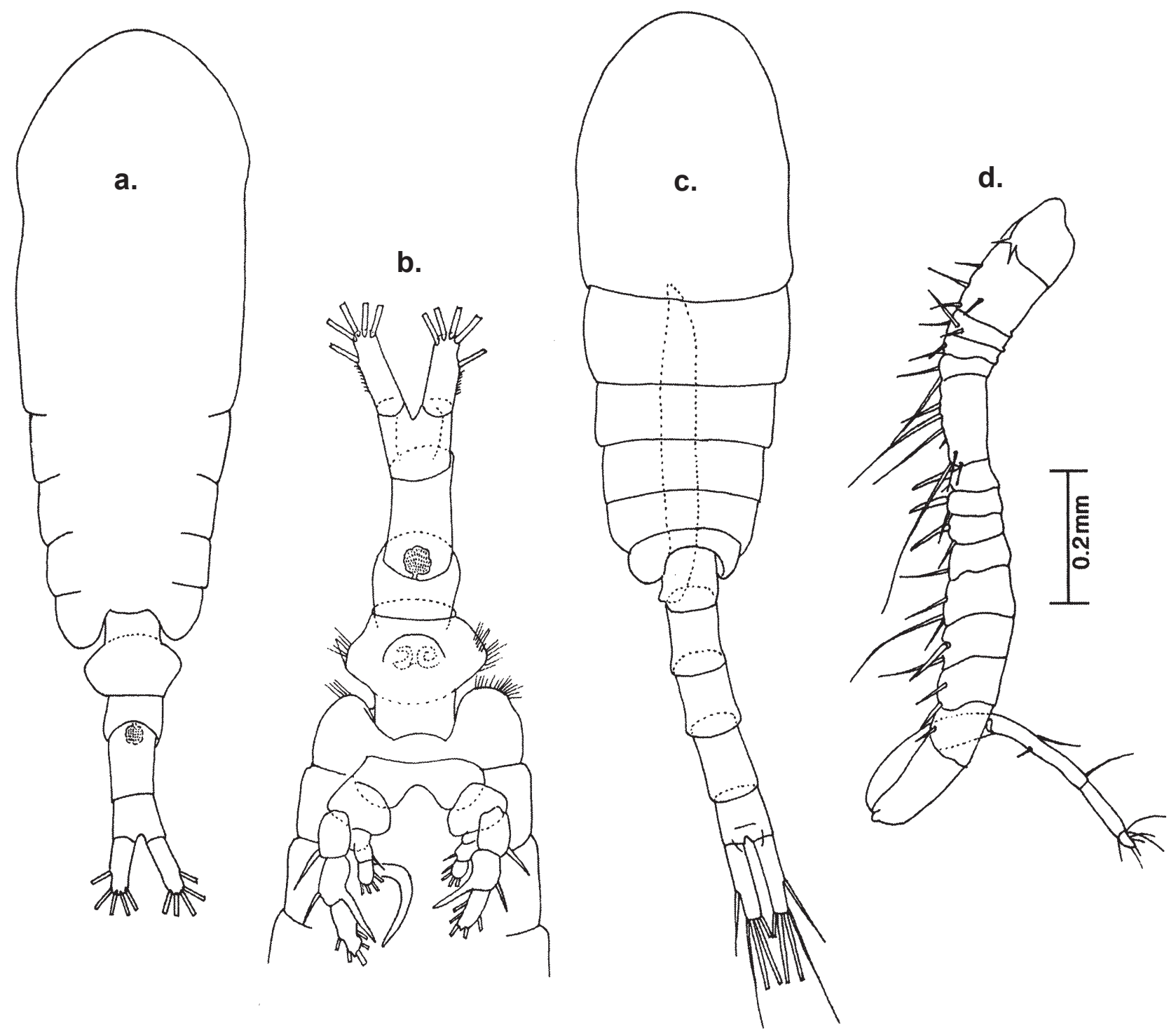

Fig. 3. Gladioferens antarcticus. a. female, ventral aspect, b. female, ventral aspect of urosome and posterior portion of prosome, c. male, dorsal aspect (dotted line represents spermatophore inside), d. male geniculate (right) antennule.

ii) Terrasovoje Lake

Material. Six males and four females collected by B. Wagner on 28 December 2001.

Measurements. Male: $\mathrm{P}[\mathrm{D}] \mathrm{L}, 0.82 \mathrm{~mm}(n=5)$; AP-RL, $1.13 \mathrm{~mm}(n=5)$. Female: P[D]L, $0.84 \mathrm{~mm}(n=4)$; AP-WL, $0.97 \mathrm{~mm}(n=4)$; AP-RL, $1.19 \mathrm{~mm}(n=4)$. The individuals from this lake are significantly smaller than those from Radok Lake.

Male fifth legs. The terminal segment of the right endopod varied considerably in the degree of armature: three specimens had all four spines, but in one of these the spine in position 4 was very small; one specimen had three spines (none in position 4); one specimen had two serrated spines (positions 1 and 2); one specimen had only a tiny spine (in position 2). The mean number of spines in this population was thus 3.0 as compared with a mean of only $0.4(3 / 7)$ in the Radok lake population. However, in this small sample half the population had a reduced armature.

iii) Beaver Lake

Material. Bayly \& Burton (1993) examined one male and ten females collected from this lake by L. Fletcher during the summer of 1990-91.

Measurements. Female: AP-RL, $1.05 \mathrm{~mm}(n=10)$ (Bayly \& Burton 1993). The length of the single male was not determined because the body was distorted, but using a female/male body size ratio of 1.05 from the other two populations, the corresponding male length would be c. $1.00 \mathrm{~mm}$. Hence this population has the smallest specimens of the three. 
a.

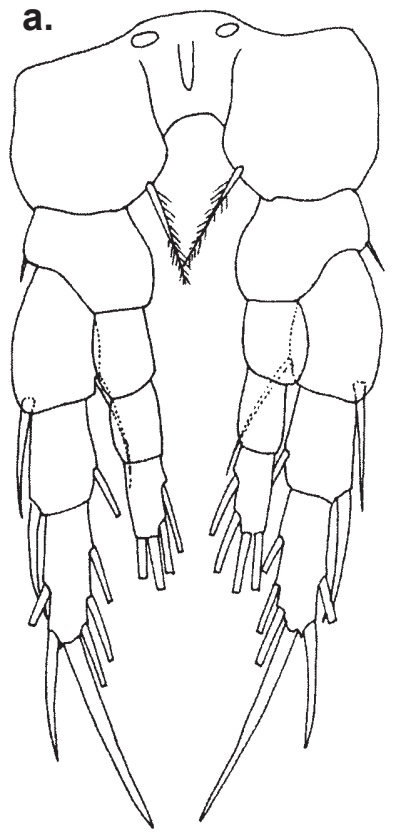

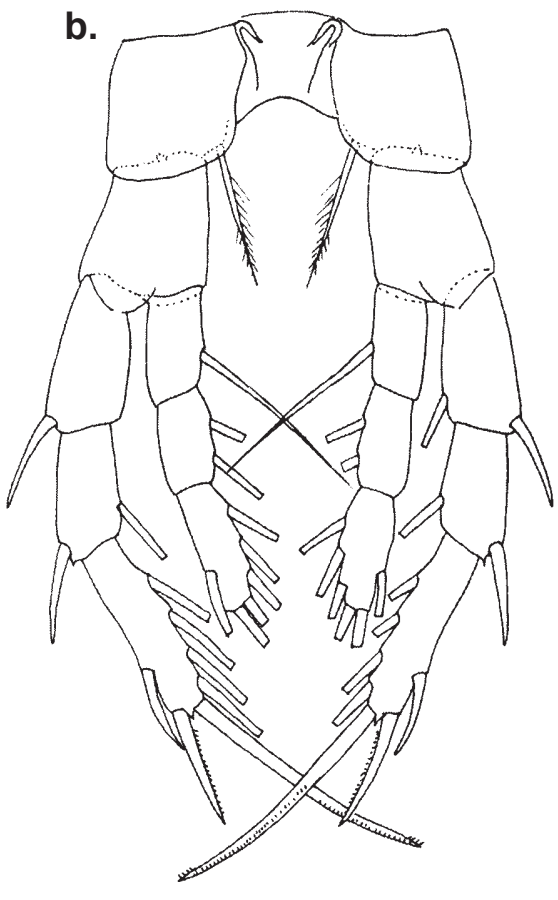

b.

c.
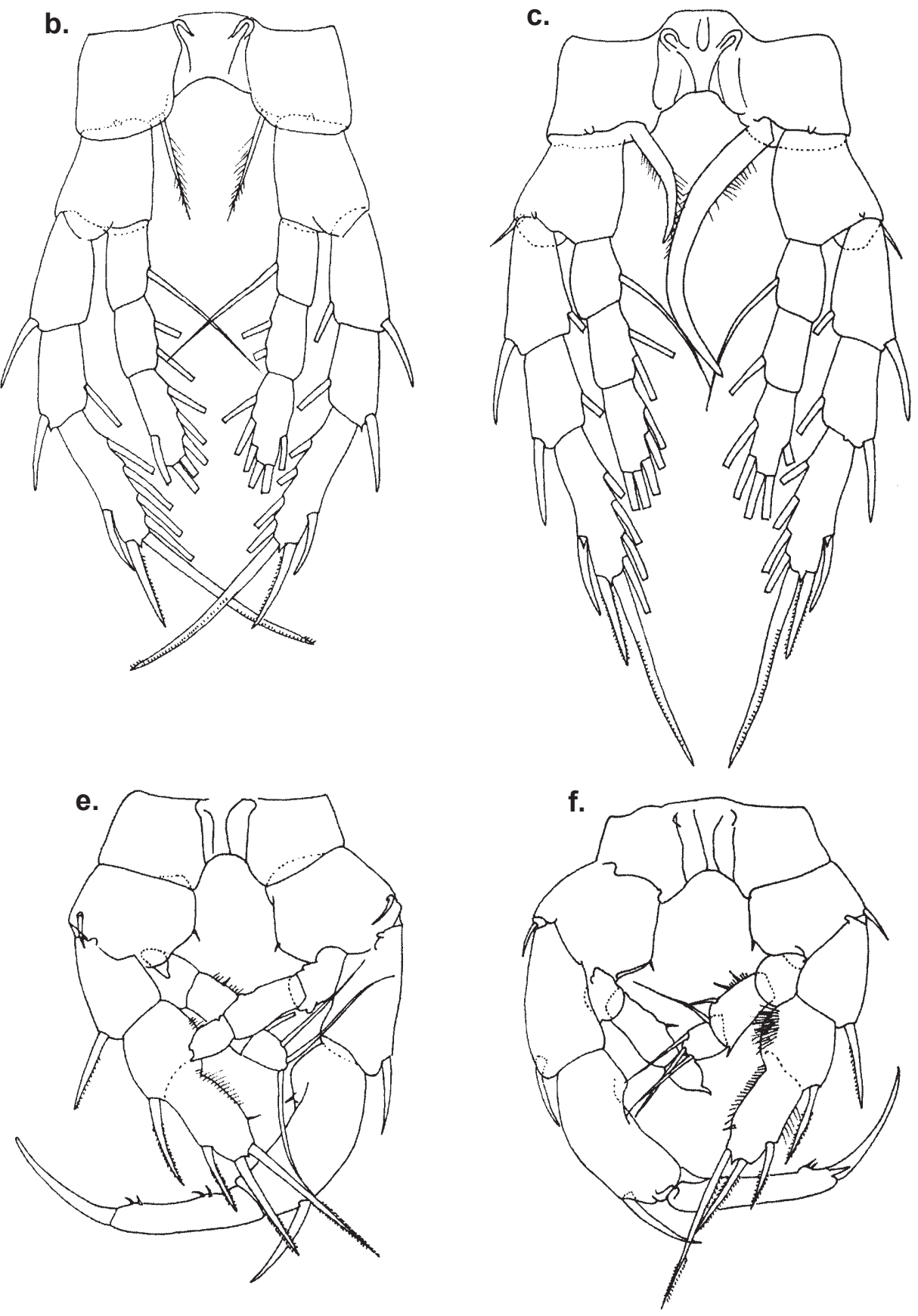

e.

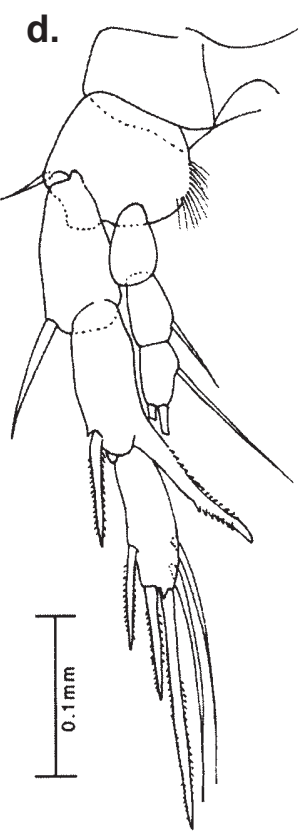

Fig. 4. Gladioferens antarcticus. a. first pair of swimming legs (P1) of female, b. fourth pair of swimming legs (P4) of male, c. fourth pair of swimming legs (P4) of female, anterior aspect, $\mathbf{d}$. fifth leg of female (half of symmetrical pair), e. fifth legs of male, posterior aspect, $\mathbf{f}$. fifth legs of male, anterior aspect.

Male fifth legs. Bayly \& Burton (1993) stated that this appendage had been drawn. This previously unpublished drawing is produced here as Fig. $2 \mathrm{f}$. This shows that the terminal segment of the right endopod has a full complement of four spines.
With data for only one male, nothing can be said at the moment regarding variation in the armature of the male right Re3. Additional material is now a priority. LaybournParry et al. (2001) confirmed the existence of a dwarf form of $B$. poppei in this lake but gave no measurements. 

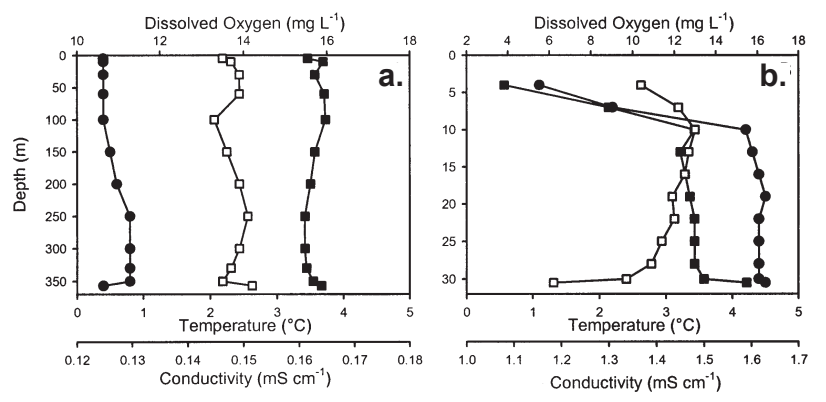

Fig. 5. Temperature (circles), in situ conductivity (closed squares) and dissolved oxygen (open squares) profiles for a. Radok Lake (27/28 January 2002), and b. Lake Terrasovoje (28 December 2001).

Someone attempting to identify the "unarmed" (meaning the male fifth right Ri3 unarmed) form of Boeckella from Radok Lake could easily be trapped into misidentifying it or describing it as a new species. However, this unarmed form still keys out correctly in Bayly's (1992a) key provided that at couplet 9 (page 24) the parenthetical comment at 9(b), "(and Ri3 bearing spines - typically 4$)$ ", is ignored.

The peculiar state of the male fifth legs in the Radok Lake population is further vindication of Bayly's (1992b) decision to place Pseudoboeckella in synonymy with Boeckella. One of the key features of the supposed distinction between these two genera was that the male fifth right endopod of Pseudoboeckella had setae or spines. If we were to apply this criterion to the Radok Lake population we would have to place some individuals in Boeckella and some in Pseudoboeckella. Bayly (1992b, p. 21) pointed out that the same untenable situation would arise with different forms of B. brevicaudata (Brady, 1875).

\section{Populations of Gladioferens antarcticus in the Bunger Hills}

Hitherto, White Smoke Lake in the Bunger Hills was the only known location for this species. However, during January 2000, further samples were collected from three other lakes in the area: Transkriptsii Gulf, Lake Pol'anskogo and Southern Lake (Fig. 1b).

\section{Taxonomy of Gladioferens antarcticus}

Bayly (1994) described G. antarcticus from White Smoke

Table I. Morphometric parameters of Beaver, Radok and Terrasovoje lakes.

\begin{tabular}{|c|c|c|c|}
\hline Location & $\begin{array}{c}\text { Beaver Lake } \\
70^{\circ} 47^{\prime} \mathrm{S} \\
68^{\circ} 20^{\prime} \mathrm{E} \\
\end{array}$ & $\begin{array}{c}\text { Radok Lake } \\
70^{\circ} 52^{\prime} \mathrm{S} \\
67^{\circ} 58^{\prime} \mathrm{E} \\
\end{array}$ & $\begin{array}{c}\text { Lake Terrasovoje } \\
70^{\circ} 33^{\prime} \mathrm{S} \\
68^{\circ} 01^{\prime} \mathrm{E} \\
\end{array}$ \\
\hline Height above sea level (m) & 0 & 7 & c. 150 \\
\hline Area $\left(\mathrm{km}^{2}\right)$ & c. 130 & 19.9 & 1.9 \\
\hline Maximum recorded depth (m) & ) $220-260^{1}$ & 367 & 31 \\
\hline
\end{tabular}

${ }^{1}$ Approximate depth of the freshwater-marine interface (Wand et al. 1988).
Lake in the Bunger Hills. Due to a technical problem experienced by the printer, the taxonomic drawings accompanying the original description of this key species lacked clarity. For this reason, the original drawings are reproduced here (Figs $3 \& 4$ ). The verbal aspects of the original description need no amendment.

\section{Discussion}

\section{Ecology of Boeckella poppei}

The three lakes in the Amery Oasis from which Boeckella poppei has been collected vary markedly in their physical and chemical characteristics (Table I). Radok Lake is the deepest known lake on the surface of Antarctica (Wand et al. 1988). Beaver Lake is an extensive epishelf lake, in which $c .200 \mathrm{~m}$ of freshwater derived from melt of the polar ice cap is dammed by a floating ice shelf and floats on denser seawater (Wand et al. 1988). Beaver Lake is connected to open marine waters under the Amery Ice Shelf, and is therefore tidal. Terrasovoje Lake is a smaller, shallower water body that receives local meltwater only. Adamson et al. (1997) showed that the Amery Oasis has not been overridden by ice since at least the Pliocene, suggesting that these three lakes could be much older than most other Antarctic lakes, which post-date the end of the last glacial period.

Each of the lakes contains freshwater, though the salinity, as reflected by the electrical conductivity, varies by a factor of over 100. Radok Lake is the most dilute of the lakes, largely because its water is derived from glacial melt from the Battye Glacier that contributes little ionic material. Lake Terrasovoje is about 10 times more saline, typical of Antarctic lakes that receive significant terrestrial input. The salinity profile of Beaver Lake is more complex, as not only is there input at the surface, but tidal entrainment of more saline marine water underlying the freshwater layer mixes salt into the upper waters. Laybourn-Parry et al. (2001) recorded salinities between 1 and $4 \mathrm{~g} \mathrm{l}^{-1}$ in the upper $180 \mathrm{~m}$ of the lake. All of the lakes are cold $\left(<5^{\circ} \mathrm{C}\right.$ throughout $)$, especially Beaver Lake and Radok Lake. However, the temperatures are unlikely to limit the distribution or growth of the zooplankton, as animals in the inshore Antarctic marine ecosystem undergo their entire life histories at even lower temperatures, commonly less than $0^{\circ} \mathrm{C}$.

The water column of Radok Lake is remarkably uniform in its chemical and physical characteristics (Fig. 5), and Adamson et al. (1997) concluded that the lake was mixed to the sediment, even at the deepest part of the lake. No measurements of chlorophyll $a$ or primary productivity have been reported for the lake, though the deep mixing, thick ice-cover and probable ultra-oligotrophic status suggest that biological production would be limited. By comparison to other deep, glacier-fed lakes in Antarctica (e.g. Henshaw \& Laybourn-Parry 2002), it is probable that 
concentrations of chlorophyll $a$ would be less than $1 \mu \mathrm{g} \mathrm{l}^{-1}$. Laybourn-Parry et al. (2001) reported that Beaver Lake was highly oligotrophic, with organic carbon loading less than $1 \mathrm{mg} \mathrm{l}^{-1}$. Chlorophyll $a$ was present at concentrations less than $1 \mu \mathrm{g} \mathrm{l}^{-1}$ throughout most of the freshwater zone. Lake Terrasovoje is probably more productive than Radok and Beaver Lakes, though no measurements of productivity or chlorophyll $a$ have been made. The sediments consist of organic rich material largely derived from microbial mats that grow around the margins of the lake.

Boeckella poppei is the only crustacean found in the water column of each of these lakes. The distribution of the animals in the water column is uncertain. The samples studied by Bayly \& Burton (1993) from Beaver Lake were collected through a tide crack at the margin of the lake, and there has been at least one previous record of animals being observed in tide cracks (Mellor \& McKinnon 1960). In contrast, Laybourn-Parry et al. (2001) only found animals in bottle samples collected from depths beneath $25 \mathrm{~m}$ at an offshore site. These authors recorded that ovigerous females carried as few as four eggs in their egg sacs, far fewer than recorded in South American populations of the species. Laybourn-Parry et al. (2001) suggested that B. poppei in Beaver Lake is living close to its limit of tolerance, is dwarfed and of low fecundity partly because of low food availability, and may have adopted a life cycle that spans several years. As for Beaver Lake, the numbers of eggs carried by ovigerous females in Lakes Radok and Terrasovoje were small: $2.5(n=2)$ and $3.3(n=3)$ respectively.

It is possible that copepods from Radok Lake could reach Beaver Lake, and therefore provide genetic input to the Beaver Lake population. The outlet to Radok Lake occurs through Pagodroma Gorge, a fluvial feature that connects the lakes (Adamson et al. 1997), and animals could be transported down the short stream that forms in most summers.

\section{Zoogeography of Boeckella poppei}

The discovery of $B$. poppei in Radok Lake and Lake Terrasovoje provides new evidence that helps to answer one of the most intriguing questions in Antarctic biogeography: What was the origin of the $B$. poppei population in Beaver Lake, considering that this species was otherwise limited to the Antarctic Peninsula and southern South America? Pugh et al. (2002) describe Bayly \& Burton's (1993) record of B. poppei from Beaver Lake as "anomalous" and suggested three possible explanations:

1) introduction via an avian or other natural vector,

2) possible (taxonomic) confusion with B. brevicaudata,

3) a recent "alien" importation from the maritime (Antarctic Peninsula) or sub-Antarctic.
The second explanation can be eliminated; a form of $B$. poppei definitely occurs in this lake. We now also have the above records of this species from two additional lakes close to Beaver Lake. Regarding the first explanation, bird transport is commonly invoked to explain the otherwise inexplicable, but is clearly an agency of minor importance in the zoogeography of freshwater calanoids. Bayly \& Morton (1978) emphasized what might be called Lowndes' Paradox: where every apparent facility for easy distribution occurs (e.g. the existence of desiccation-resistant eggs in calanoids, combined with the availability of avian transport) the species are usually remarkably restricted, while in those cases where distribution seems most difficult (e.g. the nonresistant eggs of cyclopoids) the species are often widely distributed. In general, an avian explanation for freshwater calanoid distributions has little credibility, and it should be regarded as the explanation of last resort.

So to the third explanation of Pugh et al. (2002): that B. poppei in Beaver Lake are a "recent" import from the Antarctic Peninsula or sub-Antarctic island. Considering the latter potential source, it should be noted that B. poppei does not occur on any of the sub-Antarctic islands located off the Antarctic Enderby Sector of Pugh et al. Marion Island, Prince Edward Islands and Îles Crozet all have B. vallentini (Scott, 1914), Îles Kerguelen has B. vallentini and $B$. brevicaudata, and Heard Island has $B$. brevicaudata (Bayly 1992b). We are left to consider "recent" importation from the Antarctic Peninsula. Pugh et al. (2002) make it clear by their reference to "the historic introduction of anthropogenic aliens" that by "recent" they are referring to the latter part of the Recent epoch (Holocene). However, Bayly \& Burton (1993) suggested that epishelf lakes, especially those associated with the larger Antarctic ice shelves, were highly stable systems whose existence may have antedated the Holocene (i.e. were older than $10000 \mathrm{yr}$ ). This possibility seems not to be excluded by Pugh et al. (2002) who agree that Beaver Lake could be as old as $20000 \mathrm{yr}$, so the events involved in the colonization of Beaver Lake may not be as recent as the comments by Pugh et al. (2002) suggest.

The conclusion of Pugh et al. (2002, pp. $1081 \& 1092)$ is that $B$. poppei in Beaver Lake "is a probable anthropogenic alien" imported from the Antarctic Peninsula. However, their theory of recent synanthropic introduction would now have to be extended to two further remote lakes and consequently becomes less probable. Furthermore, Mellor \& McKinnon (1960) recorded 'shrimp-like creatures', presumably B. poppei, in Beaver Lake as early as 1958 , by which time there would have been very limited chance of import, particularly from the Antarctic Peninsula. A study of the distribution of faunal remains in the sediments of Lake Terrasovoje currently underway suggests that $B$. poppei was in fact present in the lake prior to the initial human visits to the area (L. Cromer, personal communication 2003).

The comments of Pugh et al. (2002) regarding the 
Table II. Morphometric and physical characteristics of epishelf lakes in the Bunger Hills known to contain populations of Gladioferens antarcticus (data summarized from Gibson \& Andersen 2002). The surfaces of all the lakes are at sea level.

\begin{tabular}{|c|c|c|c|c|}
\hline & $\begin{array}{l}\text { White Smoke } \\
\text { Lake }\end{array}$ & $\begin{array}{c}\text { Lake } \\
\text { Pol'anskogo }\end{array}$ & $\begin{array}{l}\text { Southern } \\
\text { Lake }\end{array}$ & $\begin{array}{c}\text { Transkriptsii } \\
\text { Gulf }\end{array}$ \\
\hline \multirow[t]{2}{*}{ Location } & $66^{\circ} 19^{\prime} \mathrm{S}$ & $66^{\circ} 19^{\prime} \mathrm{S}$ & $66^{\circ} 17^{\prime} \mathrm{S}$ & $66^{\circ} 15^{\prime} \mathrm{S}$ \\
\hline & $100^{\circ} 36^{\prime} \mathrm{E}$ & $100^{\circ} 30^{\prime} \mathrm{E}$ & $100^{\circ} 29^{\prime} \mathrm{E}$ & $100^{\circ} 35^{\prime} \mathrm{E}$ \\
\hline Area $\left(\mathrm{km}^{2}\right)$ & 0.83 & 2.0 & 0.83 & 14.4 \\
\hline Max. depth (m) & 90 & 69 & 68 & 122 \\
\hline Temperature range $\left({ }^{\circ} \mathrm{C}\right)$ & $-0.2-+0.4$ & $-0.1-+0.2$ & $-0.3-+0.6$ & $-0.1-+1.1^{2}$ \\
\hline Salinity range $\left(\mathrm{g} \mathrm{L}^{-1}\right)$ & $0.02-0.08$ & 0.22 & $0.6-4.5$ & $0.5-1.0^{2}$ \\
\hline
\end{tabular}

${ }^{1}$ Oxygenated freshwater eastern basin only.

${ }^{2}$ Oxygenated portion of the water column only.

introduction of B. poppei into Beaver Lake suggest that they envisage a one-off and direct act of transmittance over thousands of kilometres. This, however, is an unnecessary postulate. It is more reasonable to suppose that several to many long-lived epishelf lakes have existed around the periphery of the continent and that there was a progressive conveyance of B. poppei from the region of the Antarctic Peninsula to the Amery Oasis over a long period of probably some thousands of years. Genotypic and phenotypic divergence occurred during this slow process of migration, and further divergence has clearly also occurred since the species reached the area. It is also possible that $B$. poppei occurred in the Amery region prior to glaciation. However, the forms of B. poppei present in Radok and Terrasovoje lakes appear to be a derived rather than a primitive form, as evidenced by spine reduction in the male. Against this, the only male from Beaver Lake examined had no spine reduction (Fig. 2f). If there are invariably four spines on the males of the Beaver Lake population, it may be that the primitive form of $B$. poppei was present in the Amery region before glaciation.

The Radok Lake form of B. poppei has not only undergone a marked reduction in body size but the armature of the male fifth right leg has also suffered considerable reduction. This phenotypic divergence is probably the product of significant genotypic divergence and suggests that the Radok Lake population has been isolated for a long time. Our knowledge of rates of evolution in Boeckella is poor and it is therefore difficult to quantify the length of isolation. Despite the uncertainty regarding the length of isolation of the Radok Lake population, the evidence is against the type of explanation advanced by Pugh et al. (2002) with respect to Beaver Lake. If the Boeckella in Radok Lake were also a recent alien import it would be expected to have similar characteristics to the Beaver Lake population, and have four spines on the male right fifth endopod, but typically it has none.

We conclude, therefore, that the Amery Oasis populations of $B$. poppei are not recent anthropogenic introductions, but rather that this species is a natural component of the lacustrine ecosystems of the area.
Ecology of Gladioferens antarcticus

Gladioferens antarcticus has now been recorded from four lakes - White Smoke Lake, Lake Pol'anskogo, Southern Lake and Transkriptsii Gulf - in the Bunger Hills. These lakes are all epishelf lakes, though it appears that the connection between White Smoke Lake and the marine environment can be cut during periods when the grounding line of the Apfel Glacier moves downstream (Doran et al. 2000, Gibson \& Andersen 2002). The physical characteristics of these lakes are summarized in Table II. All of the lakes are deep $\left(\mathrm{Z}_{\max }\right.$ from 68 to $\left.122 \mathrm{~m}\right)$, cold (maximum recorded temperatures less than $1.2^{\circ} \mathrm{C}$ ) and in general fresh (in most cases maximum salinities ranging from 0.1 to $1 \mathrm{~g} \mathrm{l}^{-1}$ ). Two of the lakes, Transkriptsii Gulf and Lake Pol'anskogo, also contain more saline, anoxic water at the base of the water column or in isolated basins (Gibson \& Andersen 2002).

Gladioferens antarcticus was present in low numbers in samples collected from all of the lakes; the cyclopoid Acanthocyclops mirnyi Borutsky \& Vinogradov, 1957 was far more abundant in every sample. It is estimated that G. antarcticus made up less than $1 \%$ of the total copepod populations in the samples. This may have been due to this species' innate scarcity, but could also be due to it inhabiting a particular, poorly sampled micro-habitat. For example, it may have been closely associated with the organic-rich sediment present in these lakes (Doran et al. 2000), which means that the animals would have been under sampled in net hauls.

All of the lakes were covered by ice up to $4 \mathrm{~m}$ thick when sampled, and it appears that the lakes have been permanently ice-covered at least since the area was first visited in the late 1940s. Both the ice and the water in the lakes is extremely clear, which allows radiation to penetrate the lake and photosynthesis to occur. Chlorophyll $a$ measurements have been made only in Transkriptsii Gulf, where concentrations between 0.37 and $0.54 \mu \mathrm{g} \mathrm{l}^{-1}$ were recorded at depths to $50 \mathrm{~m}$ (Gibson 2000). These concentrations were low compared with those of most lacustrine environments, but were comparable with those of Beaver Lake (Laybourn-Parry et al. 2001). Semiquantitative zooplankton tows in Transkriptsii Gulf suggested that highest copepod density occurred close to the oxic-anoxic interface at depths of over $80 \mathrm{~m}$. It may be that these animals were feeding on mixotrophic or heterotrophic organisms present in this zone.

\section{Zoogeography of Gladioferens antarcticus}

Before the discovery of $G$. antarcticus, the Australian-New Zealand disjunction in the distribution of the genus had attracted some attention. Following Brehm (1936), Sewell (1956) stated: "That at some time the islands of New Zealand were much more closely connected with Australia 
is ... strongly suggested by the distribution of the genus Gladioferens Henry". This comment foreshadowed one modern explanation: that the trans-Tasman disjunction may well stem from an ancient vicariant event - the separation of New Zealand from the south-eastern flanks of what is now Australia. According to Stevens (1980), New Zealand drifted away from Australia (and Antarctica) at about $85 \mathrm{Ma}$ BP, and between 80-60 Ma BP the Tasman Sea opened up to its full width. Apart from being a noted copepod systematist, Seymour Sewell was well ahead of his time as a biogeographer. He (Sewell 1956) declared his support for the theory of continental drift and stated that, "the facts of the geographical distribution of many of the Copepoda can best be explained by the drifting apart of the great land masses."

With the discovery of $G$ antarcticus, the distribution of the genus became strikingly more disjunct (see fig. 11 in Bayly 1994), and a closer look at the Australian-Antarctic disjunction was warranted. The geological map of Gondwana produced by the American Association of Petroleum Geologists (1988) shows that what is now the south-west corner of Australia was joined to what is now known as the Bunger Hills region of Antarctica. Today G. imparipes Thomson, 1946 occurs in the south-west corner of Western Australia, and G. antarcticus in the Bunger Hills. Most of the southern shores of what is now Australia became separated from the future Antarctica by a narrow marine inlet well before the end of the Cretaceous. Starting from the west, all but the region of Tasmania was "unzipped" as early as the mid-Cenomanian stage $c .95 \mathrm{Ma}$ BP) (Australian Cretaceous Palaeoenvironments Group 1987). Even if this narrow inlet did not constitute an effective barrier to dispersal at this early stage we can be reasonably confident that there was an effective barrier from the Palaeocene onwards. With this geological background, it is unnecessary to invoke dispersal to explain the existence of $G$. antarcticus in the Bunger Hills. It is reasonable to suppose that Gladioferens evolved in residual Gondwana after the departure of Africa and India but before the end of the Mesozoic (see Boeckella in Bayly 1995), and that its association with Antarctica is correspondingly ancient.

There is an entirely independent argument against recent dispersal being a valid explanation for the presence of G. antarcticus in the Bunger Hills. Bayly (1994) showed that this species is structurally quite distinct from, and more primitive than, its four consubgeners that occur in the Australasian region. More specifically, the male has symmetrical second legs and the endopods of the fifth legs are 3-segmented. In contrast, the males of Australasian species in the same subgenus have specialized (asymmetrical) second legs and the segmentation of the endopods of the fifth legs is reduced (1- or 2-segmented). How, then, could a more primitive taxon have been implanted on to the Antarctic continent from an
Australasian source by recent dispersal? If ever there was a species that bespeaks vicariance, it is G. antarcticus.

Pugh et al. (2002) erroneously stated that there are populations of Gladioferens in the Vestfold Hills and made two very surprizing claims:

a) there is no suggestion of vicariance among crustacean species on continental Antarctica, and

b) "all Continental and Maritime Antarctic Crustacea represent Holocene immigrants."

These authors correctly indicate in their table 5 that G. antarcticus is endemic to Antarctica. But how do we have an Antarctic endemic (and a primitive one at that) if all the non-marine Antarctic Crustacea are Holocene immigrants? One would need to postulate extinction at the extraAntarctic source. Where do Pugh et al. (2002) suppose that G. antarcticus came from? Bayly (1994) emphasized that there are no oceanic species of Gladioferens (small numbers of two species may be found in neritic waters), and no mention of this genus is made in catalogues of copepods recorded from the Southern Ocean (Razouls 1992, 1994, Razouls et al. 2000). Oceanic water represents a homoiosaline environment whereas Gladioferens flourishes in poikilosaline waters.

Pugh et al. (2002) state: "There is no evidence to corroborate even a single lake as a viable refugium for a pre-glacial aquatic fauna." Leaving aside the possibility that this statement may be open to question, it is irrelevant in the sense that some pre-glacial taxa may not have required a lacustrine refuge in order to survive. Gladioferens is a case in point. All that the immediate ancestor of G. antarcticus would have required was the continuous existence of a poikilosaline environment sensu Dahl (see Bayly 1967, 1975). There is no reason to suppose that even full glaciation of Antarctica (e.g. at $18000 \mathrm{yr}$ BP) would have obliterated poikilosaline environments; wherever melting ice met the oceans around the periphery of an expanded Antarctic ice-sheet, salinities would have been in a state of flux and poikilosalinity preserved. Although G. antarcticus now inhabits fresh waters, its immediate ancestor was probably a euryhaline form associated with waters of highly variable salinity. The ability of $G$. antarcticus to live in fresh waters is not unique within its genus. In Australia, G. spinosus Henry, 1919 is capable of living permanently in coastal fresh waters, including closed lakes of stable salinity (Bayly 1980), whereas most of its congeners occur in the poikilosaline waters of estuaries (Bayly 1975).

It is true that the Antarctic region has experienced large climatic changes in the course of the Cainozoic. However, the family Centropagidae, to which Gladioferens belongs, exhibits a remarkable degree of evolutionary euryhalinity (Bayly 1992a, p. 2), and this fundamentally estuarine genus contains some highly adaptable species that are both euryhaline and eurythermal and likely to survive the 
vicissitudes of climatic change.

\section{Conclusions}

Apart from marked dwarfing, at least two of the three populations of Boeckella poppei in the Amery Oasis region have diverged significantly in structure from populations of this species present in South America and West Antarctica, and are therefore not the product of recent anthropogenic introductions. Examination of more material from Beaver Lake is required to assess adequately the morphological status of that population. In the interim, however, the possibility that the primitive form of this species was present in the Amery region before late Pleistocene glaciation cannot be eliminated. Gladioferens antarcticus is a palaeoendemic species - a pre-glacial survivor. The genus Gladioferens, but not necessarily G. antarcticus itself, has had a continuous existence in waters surrounding Antarctica (land/sea or ice/sea interfaces) throughout the Cainozoic era.

\section{Acknowledgements}

The Australian Antarctic Division supplied logistic support for the field components of this study. Some of the samples were collected during fieldwork undertaken for ASAC project 1071. The comments of Drs S. Menu-Marque and P. Pugh on an earlier version of this article were greatly appreciated.

\section{References}

Adamson, D.A., Mabin, M.C.G. \& Luly, J.G. 1997. Holocene isostasy and late Cenozoic development of landforms including Beaver and Radok Lake basins in the Amery Oasis, Prince Charles Mountains, Antarctica. Antarctic Science, 9, 299-306.

American Association of Petroleum Geologists. 1988. Geological map [1:10,000,000] of Sectors of Gondwana reconstructed to their disposition c. 150 Ma. Oklahoma: American Association of Petroleum Geologists.

Australian Cretaceous Palaeoenvironments Group. 1987. Australian Cretaceous shorelines, stage by stage. Palaeogeography, Palaeoclimatology, Palaeoecology, 59, 31-48.

BAYLY, I.A.E. 1967. The general biological classification of aquatic environments with special reference to those in Australia. In Weatherley, A.H., ed. Australian inland waters and their fauna. Canberra: ANU Press, 78-104.

BAYLY, I.A.E. 1975. Australian estuaries. Proceedings of the Ecological Society of Australia, 8, 41-66.

BAYLY, I.A.E. 1980. Estuaries and coastal lakes. In Williams, W.D., ed. An ecological basis for water resource management. Canberra: ANU Press, 391-397.

BAYLY, I.A.E. 1992a. The non-marine Centropagidae (Copepoda: Calanoida) of the World [Guides to the identification of the microinvertebrates of the continental Waters of the World No.2]. The Hague: SPB Academic Publishing, 30 pp.
BAYLY, I.A.E. 1992b. Fusion of the genera Boeckella and Pseudoboeckella and a revision of their species from South America and sub-Antarctic islands. Revista Chilena de Historia Natural, 65, 17-63.

BAYLY, I.A.E. 1994. Gladioferens Henry (Copepopda: Calanoida) discovered in Antarctica: G. antarcticus sp. nov. described from a lake in the Bunger Hills. Polar Biology, 14, 253-259.

BAYLY, I.A.E. 1995. Distinctive aspects of the zooplankton of large lakes in Australasia, Antarctica and South America. Marine and Freshwater Research, 46, 1109-1120.

BAyly, I.A.E. \& Burton, H.R. 1993. Beaver Lake, Antarctica, and its population of Boeckella poppei (Mrázek) (Copepoda: Calanoida). Verhandlungen. Internationale Vereinigung für Theoretische und Angewandte Limnologie, 25, 975-978.

BAYLY, I.A.E. \& MoRTON, D.W. 1978. Aspects of the zoogeography of Australian microcrustaceans. Verhandlungen. Internationale Vereinigung für Theoretische und Angewandte Limnologie, 20, $2537-2540$.

BReHM, V. 1936. Über die tiergeographischen Verhaltnisse der circumantarctischen Süsswasserfauna. Biological Reviews, 11, 477-493.

Doran, P.T, Wharton, R.A., Lyons, W.B., Des Marais, D.J. \& ANDERSEN, D.T. 2000. Sedimentology and geochemistry of a perennially ice-covered epishelf lake in Bunger Hills Oasis, East Antarctica. Antarctic Science, 12, 131-140

GiBson, J.A.E. 2000. The environment of the Bunger Hills. Kingston, Tasmania: Australian Antarctic Division, $92 \mathrm{pp}$.

Gibson, J.A.E. \& ANDERSEN, D.T. 2002. Physical structure of epishelf lakes of the southern Bunger Hills, East Antarctica. Antarctic Science, 14, 253-262.

Henshaw, T. \& Laybourn-Parry, J. 2002. The annual patterns of photosynthesis in two large, freshwater, ultra-oligotrophic Antarctic lakes. Polar Biology, 25, 744-752.

Laybourn-Parry, J. \& Marchant, H.J. 1992. Daphniopsis studeri (Crustacea: Cladocera) in lakes of the Vestfold Hills, Antarctica. Polar Biology, 11, 631-635.

Laybourn-Parry, J., Quayle, W.C., Henshaw, T., Ruddell, A. \& Marchant, H.J. 2001. Life on the edge: the plankton and chemistry of Beaver Lake, an ultra-oligotophic epishelf lake, Antarctica. Freshwater Biology, 46, 1205-1217.

Mellor, M. \& McKinnon, G. 1960. The Amery Ice Shelf and its hinterland. Polar Record, 10, 30-34.

Pugh, P.J.A., Dartnall, H.J.G. \& McInNes, S.J. 2002. The non-marine Crustacea of Antarctica and the islands of the Southern Ocean: biodiversity and biogeography. Journal of Natural History, 36, 1047-1103.

Razouls, C. 1992. Inventaire des copépodes planctoniques marins antarctiques et sub-antarctiques. Vie et Milieu, 42, 337-343.

Razouls, C. 1994. Manuel d'identification des principales espèces de copépodes pélagiques antarctiques et subantarctiques. Annales de L'institut Oceanographique Nouvelle Série, 70, 204 pp.

Razouls, S., Razouls, C. \& De Bovée, F. 2000. Biodiversity and biogeography of Antarctic copepods. Antarctic Science, 12, 343-362.

SEwELL, R.B.S. 1956. The continental drift theory and the distribution of the Copepoda. Proceedings of the Linnean Society of London, 166, 149-177.

Stevens, G.R. 1980. New Zealand Adrift. Wellington: A.H. \& A.W. Reed, $442 \mathrm{pp}$.

Wand, U., Hermichen, W.-D., Bruggemann, E., Zierath, R. \& Klokov, V.D. 1988. Stable isotope and hydrogeochemical studies of Beaver Lake and Radok Lake, Mac. Robertson Land, East Antarctica. Zentralinstitut für Isotopen und Strahlenforschung Mitteilungen, 143, 99-111. 